\title{
COMPARATIVE EFFECTS OF RAISED BED AND TRADITIONAL FLAT BASIN ON WHEAT YIELD AND WATER PRODUCTIVITY UNDER EGYPTIAN CONDITIONS
}

\author{
Samir M. Ismail ${ }^{1}$, Abdelsamie Thabet ${ }^{2}$, Ahmed Abdel El-Al ${ }^{3}$, Abdelaziz I. Omara ${ }^{4 *}$ \\ ${ }^{1}$ Prof. of Irrigation and Drainage Eng. Systems, Ag. and Biosystems Eng. Dept., Fac. of Ag., \\ Alexandria U., Egypt. \\ ${ }^{2}$ MSc Stud. Ag. and Biosystems Eng. Dept., Fac. of Ag., Alexandria U., Egypt. \\ ${ }^{3}$ Lecturer of Irrigation and Drainage Eng. Systems, Ag. and Biosystems Eng. Dept., Fac. of Ag., \\ Alexandria U., Egypt. \\ ${ }^{4}$ Assoc. Prof. of Irrigation and Drainage Eng. Systems, Ag. and Biosystems Eng. Dept., Fac. of Ag., \\ Alexandria U., Egypt. \\ * E-mail: abdelaziz.omara@alexu.edu.eg
}

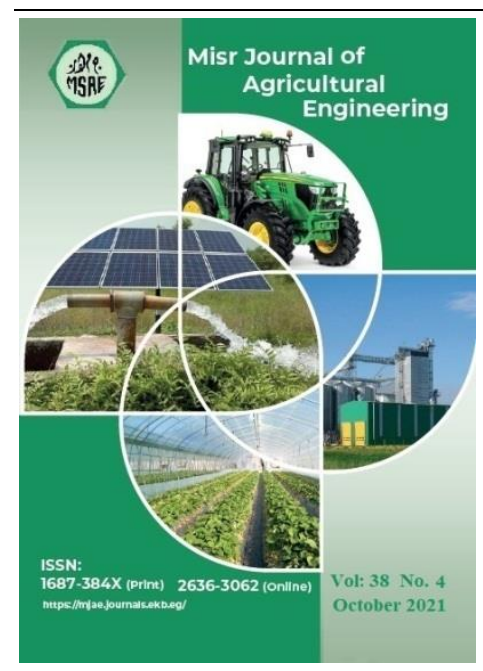

(ㅇ Misr J. Ag. Eng. (MJAE)

\begin{abstract}
Field experiments were carried out at Sakha Agricultural Research Station in Egypt to compare the effect of the newly developed raised bed technique with different bed widths (RB130, RB100, RB80 cm) on wheat productivity to the conventional flat basin (FB) method during 2019/2020. The statistical analyses were carried out using a randomized complete block design. According to the results of statistical analysis, using RB130 cultivation gave the highest significant averages of water-saving (21.81\%) and the highest averages of wheat 1000 kernels weight $(50.05 \mathrm{~g})$ over the FB method. However, no significant differences were found between RB130 and $F B$ method, which produced the highest averages of grain yield, straw yield, and biological yield. Wheat sowing on FB gave the highest significant average of grain yield, straw yield, and biological yield than RB100, RB80 at 5\% level of significance, but there were no significant differences in the number of kernels per spike, kernel weight spike, and harvest index ratio between wheat sowing on FB and RB130, RB100 or RB80. There were no significant differences in the number of kernels per spike, kernel weight spike, number of spikes per $m 2$, straw yield, biological yield, and harvest index ratio at $5 \%$ level of significance between wheat sowing on RB130, RB100, RB80. But wheat sowing on RB130 produced the highest significant average of crop water productivity and grain yield than RB80 at $5 \%$. Finally, according to the study findings, using raised beds cultivation resulted in saving irrigation water by 15 21\% compared to a flat basin.
\end{abstract}

\section{INTRODUCTION}

$\mathrm{E}$ gypt has experienced severe water scarcity in recent years, despite the Nile River is the primary source of freshwater, and Egypt's agricultural sector is also regarded as one of the most water-intensive sectors (Khalifa et al., 2019). The agricultural sector consumes more than $84 \%$ of the available water resources (El-Beltagy, A.T., 2008). 
Egypt's water scarcity has surpassed the 1,000 $\mathrm{m}^{3} /$ capita/year mark. Egypt's problem is figuring out how to produce enough food using less water (Swelam, 2017). According to (ICARDA, 2020) surface irrigation is currently used on the majority of Egypt's irrigated land, and it is the main irrigation system in ancient cultivated lands covering a total area of 6.5 million feddan (2.73million ha) despite its very low water efficiency in the field, this method of irrigation consumes $61 \%$ of the total water supply. Working to improve this system will save a significant amount of irrigation water, which could be used to expand horizontally.

Wheat is still the most important cereal crop in Egypt, as it is in many other parts of the world, but due to the growing population and limited crop area as well as water supplies, local production has fallen short of meeting demand. Increasing the production of both water and wheat is thus the top consideration of field irrigation and crop specialists. Planting techniques are one of the most important factors influencing wheat yield. Now, due to increasing knowledge and a desire to increase the productivity of crop water on farms, flat basin irrigation is slowly replaced by a bed furrow irrigation system popularly known as raised beds (Akbar, et al., 2016). The method was developed in the Yaqui Valley of Mexico, where it was adopted by more than $90 \%$ of farmers (Hassan, 2015). Raised bed systems have been identified as an important component of increased wheat production packages in Egypt's water management research to achieve higher productivity in irrigated agriculture. This technology was implemented in 22 governorates as part of the Egyptian government's national initiative to achieve self-sufficiency in wheat production and large-scale agricultural intensification, where Egyptian farmers successfully achieved higher yields while saving irrigation water (Swelam, 2017).

With the above facts, importance, and necessity in mind, a study was carried out to compare the effects of a raised bed and traditional flat basin on wheat crop yield and water productivity under Egypt's climatic conditions.

\section{MATERIALS AND METHODS}

\section{Site Description}

Field experiments were carried out at the Sakha Agricultural Research Station in Egypt's Kafr el-sheik Governorate during 2019/2020. The effect of the newly raised bed technique with different bed widths $(80,100$, and $130 \mathrm{~cm})$ on wheat productivity will be studied in comparison to the traditional basin method.

The site is located at $30^{\circ} 57^{\prime} \mathrm{E}$ longitude and $31^{\circ} 07^{\prime} \mathrm{N}$ latitude, with an elevation of approximately 6 meters above mean sea level. During the growing season, the wheat variety Maser 1 (Triticum aestivum L) was sown (It was obtained from the Sakha Research Institute) and all agricultural practices were carried out in the same manner as recommended in the farm study. Maize was the previous summer crop (Zea maize L). According to Klute (1987), the particle size distribution and some soil water constants are presented in Table (1).

\section{Preparation of Land and Sowing of Crop}

The land at the experimental site was prepared by deep Ploughing to penetrate any cultivation or salt-pan that has formed and to permit the even growth of the extensive root system of wheat plants. Then soil leveled using a laser leveling machine. Raised beds were prepared using the machine (It was obtained from the ICARDA project) that used to prepare the soil for 
raised bed planting as shown in Fig (1). The width of preformed beds was $80 \mathrm{~cm}$ with 7 defined planting rows, $50 \mathrm{~cm}$ with 5 defined planting rows, and $30 \mathrm{~cm}$ with 3 defined planting rows. The furrow spacing was 130,100 , and $80 \mathrm{~cm}$. While for a traditional method the farmers' practice (flat basin) was adopted. The seed rate was kept as $119 \mathrm{~kg}$ per hectare.

Table (1): Some physical characteristics and some soil water constants of the studied site before cultivation

\begin{tabular}{|c|c|c|c|c|c|c|c|c|}
\hline \multirow{2}{*}{$\begin{array}{c}\text { Soil } \\
\text { Depth, } \\
\text { cm. }\end{array}$} & \multicolumn{3}{|c|}{ Particle Size Distribution } & \multirow{2}{*}{$\begin{array}{l}\text { Texture } \\
\text { classes }\end{array}$} & \multirow[b]{2}{*}{ FC \% } & \multirow[b]{2}{*}{ PWP \% } & \multirow[b]{2}{*}{ AW \% } & \multirow{2}{*}{$\begin{array}{c}\text { Bd } \\
\mathrm{g} \mathrm{cm}^{-3}\end{array}$} \\
\hline & Sand & Silt $\%$ & Clay\% & & & & & \\
\hline $0-15$ & 16.6 & 19.4 & 64.0 & Clay & 47.3 & 25.0 & 22.3 & 1.16 \\
\hline $15-30$ & 19.2 & 17.9 & 62.9 & Clay & 39.9 & 21.5 & 18.4 & 1.19 \\
\hline $30-45$ & 17.6 & 19.8 & 62.6 & Clay & 38.1 & 21.1 & 17.0 & 1.23 \\
\hline $45-60$ & 18.8 & 19.6 & 61.6 & Clay & 37.4 & 20.3 & 17.1 & 1.31 \\
\hline Mean & 18.1 & 18.8 & 62.8 & Clay & 40.7 & 22.0 & 18.7 & 1.22 \\
\hline
\end{tabular}

Where: FC $\%=$ Soil field capacity, PWP $\%=$ Permanent wilting point, AW $\%=$ Available water and $\mathrm{Bd}\left(\mathrm{g} \mathrm{cm}^{-3}\right)=$ Soil bulk density

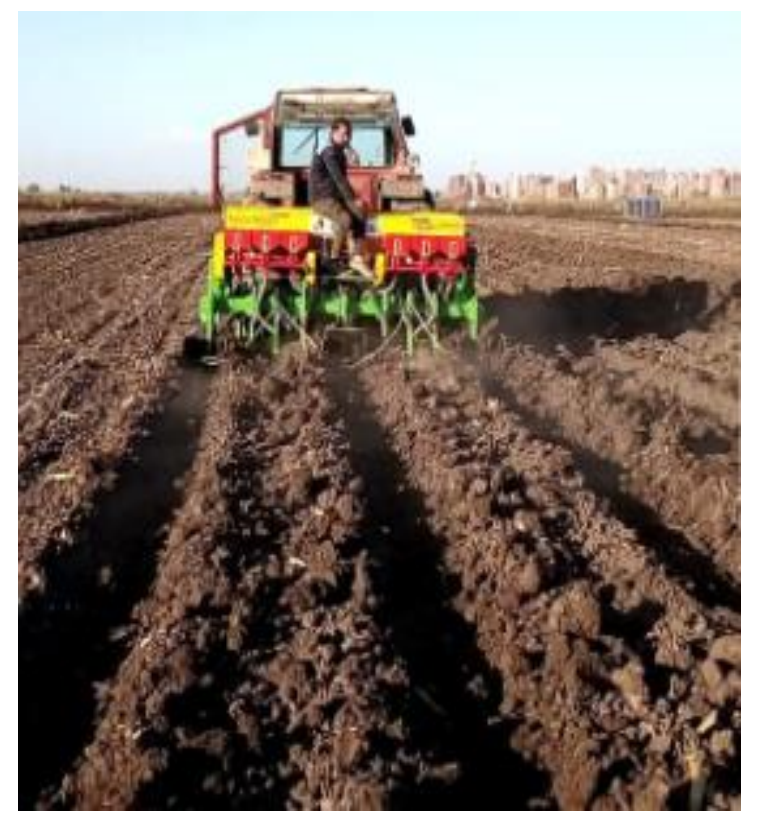

Figure (1): A new machine is used to prepare the soil for raised bed planting obtained from ICARDA project to help farmers in improving wheat cultivation in Egypt.

\section{Experimental Design}

The experimental site consisted of four borders divided into four different treatment groups, with three replicates for each treatment. The detailed layout of the experimental field is shown in Fig (2). A randomized complete block design (RCBD) with three replications was used with three raised bed widths, i.e., 80,100 , and $130 \mathrm{~cm}$, and the traditional flat basin (FB) method. And the statistical analysis was conducted using SAS 9.1 for Windows. The least significant differences (LSDs) were used to compare treatment means based on various variables to estimate the feasibility of bed planting to increase wheat production and save water. 


\section{Control Unit}

The pump $6.5 \mathrm{hp}$ with a gasoline engine and $900 \mathrm{~L} / \mathrm{min}$ inflow rate at $3600 \mathrm{rpm}$ under $26 \mathrm{~m}$ water head and $75 \mathrm{~mm}$ inside diameter of the water outlet.

\section{Measurements}

\section{Water applied}

Applied irrigation water has been managed and measured by a flow meter mounted on a small pump positioned at the irrigation entrance to the experimental plots. The applied irrigation water was measured for each plot of all treatments based on pre-and post-irrigation flow meter readings. The Tco was measured as a routine farmer's practice, avoiding submerging the ridge of the raised bed with irrigation water.

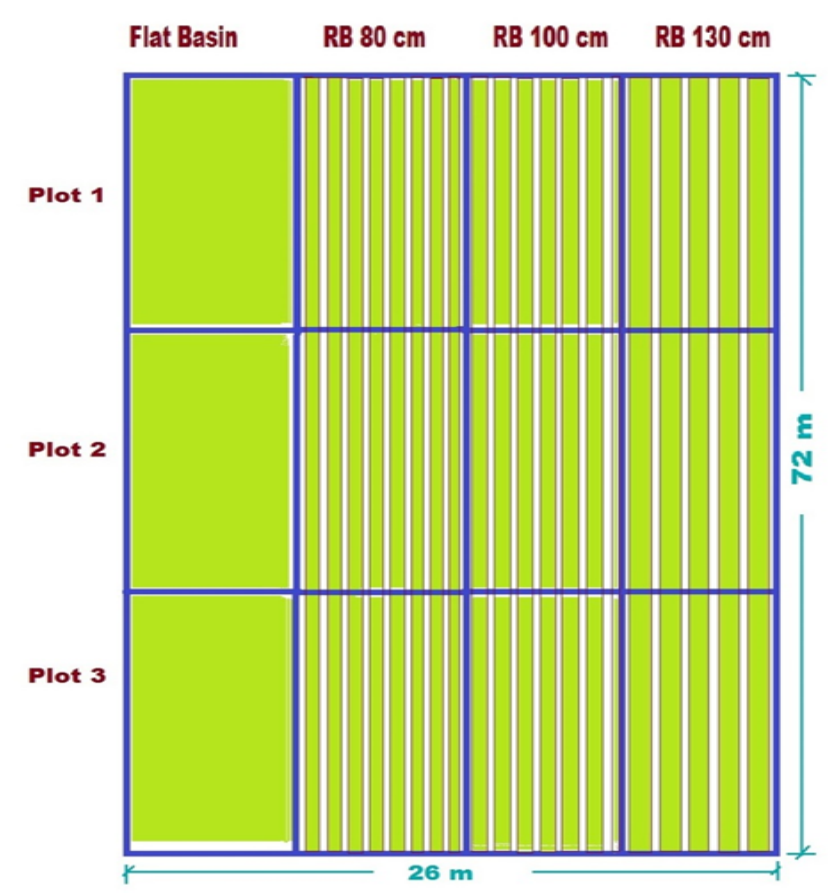

Figure (2): Layout of the experimental site

\section{Water productivity (WP)}

Water productivity was calculated by dividing grain yield by overall applied irrigation water as well as described as follows (Ali, M.H., M.R. Hoque, A.A. Hassan, 2007) and (Ismail S.,1993):

Where:

$$
\mathrm{WP}=\mathrm{GY} / \mathrm{W}_{\mathrm{app}}
$$

$$
\begin{aligned}
& \mathrm{WP}=\text { Water productivity }\left(\mathrm{Kg} \mathrm{m}^{-3}\right) \\
& \left.\mathrm{GY}=\text { grain yield }(\mathrm{kg} \mathrm{ha})^{-1}\right) \\
& \mathrm{W}_{\mathrm{app}}=\text { irrigation applied water }\left(\mathrm{m}^{3} \mathrm{ha}^{-1}\right) .
\end{aligned}
$$

\section{E Growth and yield attributes}

At 90 and 120 days after planting, ten plants were randomly selected from each plot to assess the plant height $(\mathrm{cm})$ by measuring the length of the main stem from the surface of the soil to the top of the plant. During harvesting (180 days from sowing), the number of spikes $/ \mathrm{m}^{2}$ was calculated by counting all spikes per square meter picked randomly from each plot. Fifteen 
plants have been randomly taken from each plot to test the next characters: -Number of kernels per spike and kernels weight per spike $(\mathrm{g})$.

Plants of the one-meter square were harvested from each plot, air-dried, and weighed to measure straw, grain yield, 1000 kernels weight (g), biological yield, and the harvest index (Threshing was performed by hand, and grains were measured by a balance in kilograms and then converted into ton $\mathrm{ha}^{-1}$ ).

\section{RESULTS AND DISCUSSION}

\section{Irrigation Water Applied}

The data in Table (2) show that there are significant $(P=0.05)$ differences between treatments. For sowing on raised beds with widths of $130,100,80 \mathrm{~cm}$, and flat basin irrigation system, the applied irrigation water was $0.446,0.451,0.484$, and $0.570 \mathrm{~m}^{3} / \mathrm{m}^{2}$, respectively. The applied water for wheat sowing on raised beds with widths of 130,100, and $80 \mathrm{~cm}$ was lower than flat basin by $0.124,0.119$, and $0.086 \mathrm{~m}^{3} / \mathrm{m}^{2}$, which were further calculated to be 1240 , 1190 , and $860 \mathrm{~m}^{3} \mathrm{ha}^{-1}$, respectively. Similarly, the volume of water applied to wheat crop under raised beds at widths of 130, $100 \mathrm{~cm}$ was lower than raised beds at a width of $80 \mathrm{~cm}$ by 0.038 and $0.033 \mathrm{~m}^{3} / \mathrm{m}^{2}$, which was further calculated to be 380 and $330 \mathrm{~m}^{3} \mathrm{ha}^{-1}$, respectively.

On the other side, Fig (3) indicates that the rate of irrigation water savings (\%) for wheat sowing on raised beds at widths of 130,100 , and $80 \mathrm{~cm}$ relative to a flat basin. Figure (4) shows the total volume of water applied in unit $\mathrm{m}^{3} \mathrm{ha}^{-1}$ to wheat crops under raised beds and a flat basin irrigation system, where the flat basin was the highest system that used water during the growing season.

These results are largely in line with those recorded by Swelem et al. (2018) that reported that using raised beds at the width of 120 or $100 \mathrm{~cm}$ with $180 \mathrm{~kg} \mathrm{~N} \mathrm{ha}^{-1}$ gave the highest significant averages of wheat grain yield, also substantial water saving (15\%) over the raised beds at the width of $75 \mathrm{~cm}$ with low N level treatments. Swelam (2017) reported that the use of raised-bed cultivation resulted in a $25 \%$ reduction in irrigation water. Zaman et al., (2018) said that growing wheat in a raised bed saves $14.30 \%$ more water than a flatbed. Akbar et al., (2007) said that according to the data obtained from the farmers; about 36\% (130 cm furrow center gap) of water was saved for wide beds and about $10 \%$ for narrow beds (65 cm furrow center gap) for wheat crops. And Akbar et al., (2010) reported that the lower water application within the PRB compared to basin treatments was found to be closely associated with bed width. The narrow beds used 3-7\% less water than the basins, while the medium and wide beds used $16-17 \%$ and $18-22 \%$ less, respectively.

Earlier studies (R. N. Ahmad and N. Mahmood, 2005; Akbar et al., 2016; Jat et al., 2011; Zaman et al., 2018) have also reported similar or higher saving in irrigation water wheat on raised beds compared flat with $15-23 \%$ reduction in irrigation water use. Such advantages stem from the fact that the use of furrows/beds accelerates the velocity at which irrigation water reaches the other end of the field and thus reduces the amount of irrigation water used, as furrows cover less than half of the field surface, resulting in fewer water losses. That indicates there were essential variables that helping save water, such as irrigation management and the design of the irrigation system used according to Kukal et al., (2010) that stated the effects of the beds are dependent on irrigation management, soil type, and bed age. And it is 
also likely to be affected by many factors such as soil surface levelness, depth to the water table, and field size and shape with irrigation flow rate.

Table (2): Volume of water applied to wheat crop under raised beds and flat basin

\begin{tabular}{cccccc}
\hline Treatments & $\begin{array}{c}\text { 1st } \\
\text { Irrigation } \\
\mathbf{m}^{3} / \mathbf{m}^{2}\end{array}$ & $\begin{array}{c}\text { 2nd } \\
\text { Irrigation } \\
\mathbf{m}^{3} / \mathbf{m}^{2}\end{array}$ & $\begin{array}{c}\text { 3rd } \\
\text { Irrigation } \\
\mathbf{m}^{3} / \mathbf{m}^{2}\end{array}$ & $\begin{array}{c}\text { 4th } \\
\text { Irrigation } \\
\mathbf{m}^{3} / \mathbf{m}^{2}\end{array}$ & $\begin{array}{c}\text { Applied } \\
\text { water } / \text { season } \\
\left(\mathbf{m}^{3} / \mathbf{m}^{2}\right)\end{array}$ \\
\hline Flat Basin & 0.1584 & 0.1598 & 0.1361 & 0.1156 & $\mathbf{0 . 5 7 0} \mathbf{A}^{\mathrm{A}}$ \\
RB 130 cm & 0.1013 & 0.1386 & 0.1052 & 0.1005 & $\mathbf{0 . 4 4 6}^{\mathrm{D}}$ \\
RB 100 cm & 0.1083 & 0.1392 & 0.1024 & 0.1015 & $\mathbf{0 . 4 5 1 ^ { \mathrm { C } }}$ \\
RB 80 cm & 0.1122 & 0.1500 & 0.1105 & 0.1114 & $\mathbf{0 . 4 8 4}$ \\
\hline
\end{tabular}

Mean with the same letters are not significantly different at $\mathrm{P}=0.05$

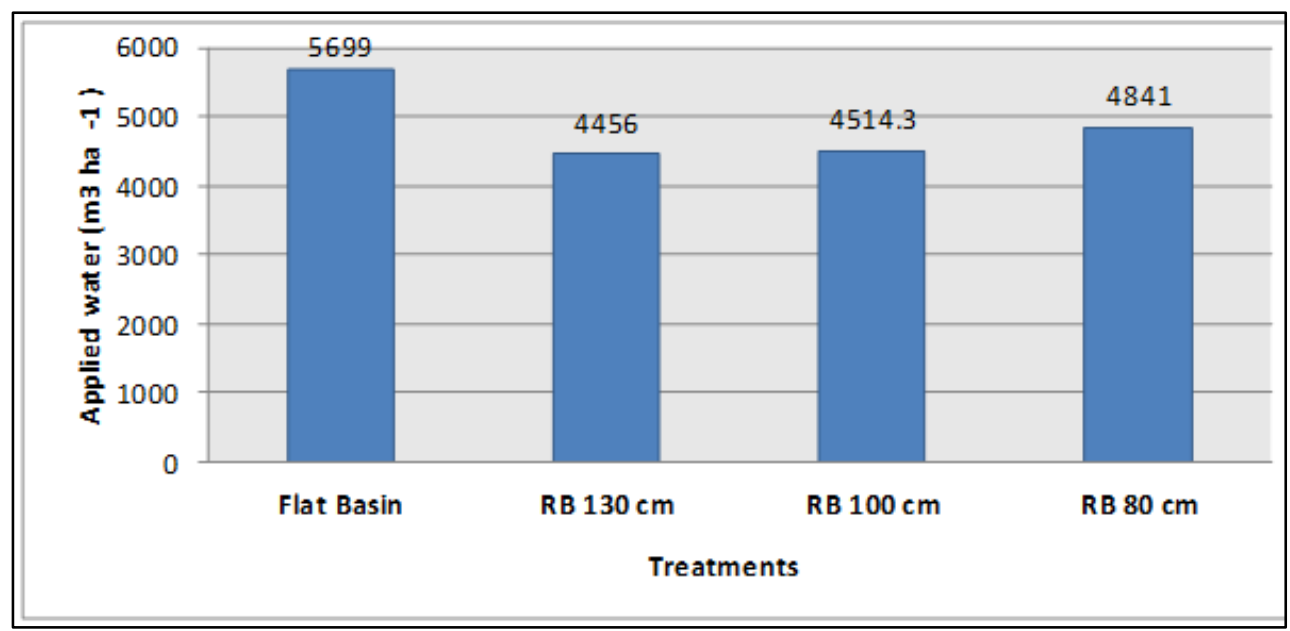

Figure (3): Total volume of water applied to wheat crop under raised bed and flat basin

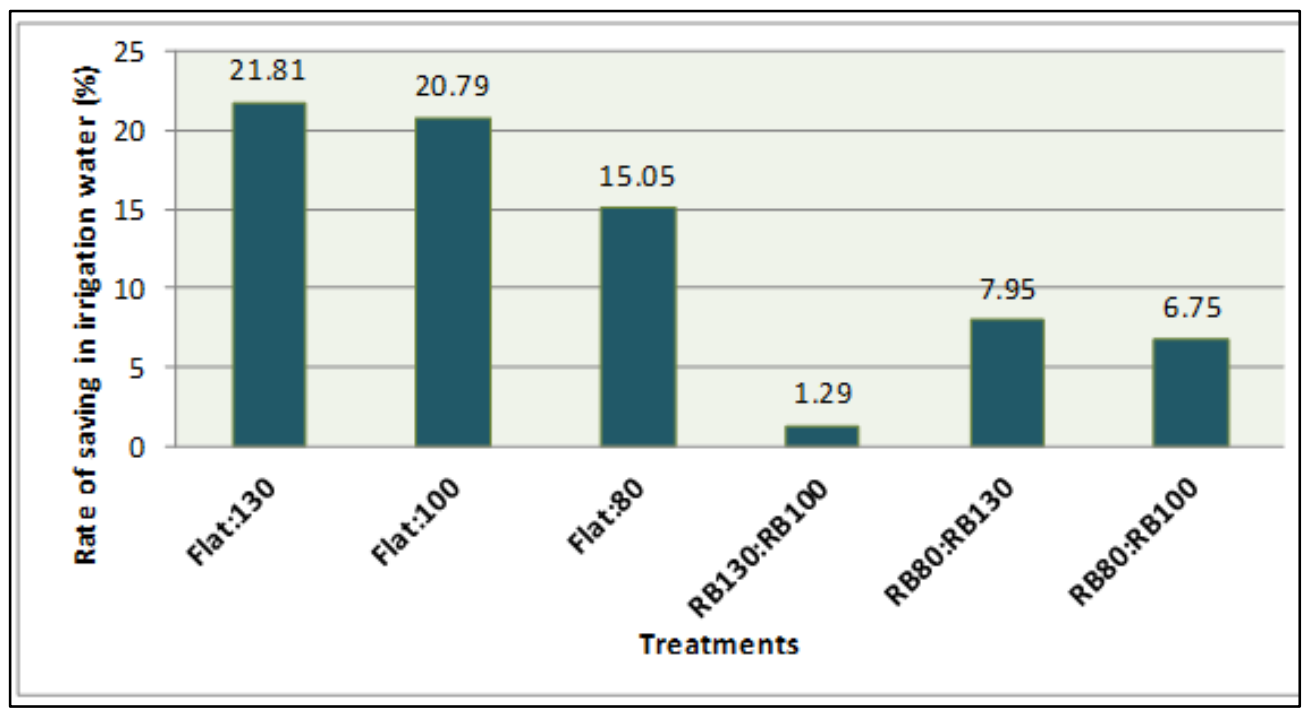

Figure (4): Rate of saving in irrigation water (\%) under the raised bed and flat basin

\section{Crop Water Productivity}

The water-saving in raised beds system directly relates to the productivity of the water as shown in Table (3). Data in Table (3) reveal that the water productivity of the wheat crop was significantly higher for RB $130 \mathrm{~cm}$ than RB $80 \mathrm{~cm}$ at a $5 \%$ level of significance, while there 
weren't significant differences between RB130, RB100 cm, and FB for wheat. And also, there weren't significant differences between FB, RB100 cm, and RB80 cm at a $5 \%$ level of significance. The highest average water productivity was obtained by growing wheat on RB $130 \mathrm{~cm}$ with a value of $1.7863 \mathrm{~kg} / \mathrm{m}^{3}$, while the average water productivity for $\mathrm{FB}, \mathrm{RB} 100$, and RB80 $\mathrm{cm}$ were $1.508,1.413$, and $1.208 \mathrm{~kg} / \mathrm{m}^{3}$ respectively. Thus, wider beds are preferred to narrow beds, because it reduces un-cropped furrow area, increases land-use efficiency, and saves water irrigation, which has improved crop water productivity.

These results are in agreement with those of Zaman et al., (2018) who indicated that maximum water use productivity $\left(1.67 \mathrm{~kg} \cdot \mathrm{m}^{-3}\right)$ was seen in the raised bed, although a minimum $\left(1.21 \mathrm{~kg} \cdot \mathrm{m}^{-3}\right)$ observed in flatbed irrigation. Roth et al., (2005) showed that wheat cultivated on raised beds with furrow irrigation provided $1.96-1.99 \mathrm{~kg}$ of grain per $\mathrm{m}^{3}$ of water, but only $1.34-1.41 \mathrm{~kg}$ of grain on flat planting in the underground well irrigation region and $0.8-1.0 \mathrm{~kg}$ of grain on flat cultivation in the Yellow River flood irrigation region, WUE based on the quantity of grain produced per $\mathrm{m}^{3}$, improved by $40-90 \%$ on raised beds, mostly because more water was used by flat while planting with flood irrigation.

Swelam (2017) also indicated that applied water saved approximately $1.30 \mathrm{~m}^{3} / \mathrm{ha}$, and farmers' incomes increased by more than $10 \%$. Water productivity potential has improved from $1.0 \mathrm{~kg} / \mathrm{m}^{3}$ to $1.5 \mathrm{~kg} / \mathrm{m}^{3}$. Through encouraging and implementing this proven technology, water savings in Egypt for wheat cultivation alone could hit more than 1.5 billion $\mathrm{m}^{3} /$ year. With the large-scale implementation of such action by growers, at least 6 billion $\mathrm{m}^{3}$ of applied water could be preserved in the county's water supply for winter and summer crop rotation.

The results show that, while the FB method achieved the highest grain yield with an average yield of (8.5907 ton/ha), it did not give the highest productivity per unit of water, where the average productivity per unit of water was $1.508 \mathrm{~kg} / \mathrm{m}^{3}$ because $\mathrm{FB}$ planting used a lot of irrigation water during the season. The RB $130 \mathrm{~cm}$ method, on the other hand, did not achieve the highest grain yield, which amounted to (7.9583 ton/ha), coming in second to the FB method, but it gave the highest productivity per unit of water, which was $1.7863 \mathrm{~kg} / \mathrm{m} 3$, due to the reduced amount of water applied by $21.81 \%$.

Table (3): Crop water productivity $\left(\mathrm{kg} / \mathrm{m}^{3}\right)$ of wheat crop under raised beds and flat basin

\begin{tabular}{|c|c|c|c|c|c|}
\hline \multirow[t]{2}{*}{ Treatments } & \multicolumn{3}{|c|}{$\begin{array}{c}\text { Productivity of irrigation water } \\
\mathrm{kg} / \mathrm{m}^{3}\end{array}$} & \multirow{2}{*}{$\begin{array}{l}\text { Mean } \\
\mathbf{k g} / \mathbf{m}^{3}\end{array}$} & \multirow{2}{*}{ فำ } \\
\hline & Plot 1 & Plot 2 & Plot 3 & & \\
\hline Flat-Basin & 1.438 & 1.302 & 1.783 & $1.508^{a b}$ & \\
\hline RB 130 & 1.627 & 1.785 & 1.947 & $1.786^{\mathrm{a}}$ & $\stackrel{n}{5}$ \\
\hline RB 100 & 1.326 & 1.584 & 1.330 & $1.413^{a b}$ & $\stackrel{+}{0}$ \\
\hline RB 80 & 1.216 & 1.387 & 1.020 & $1.208^{b}$ & \\
\hline
\end{tabular}

Mean with the same letters are not significantly different at $P=0.05$

\section{Growth and Some Yield Attributes \\ * Plant Height}

Data presented in Table (4) shows the effect of the planting method on plant height $(\mathrm{cm})$ at 90 days and 120 days after sowing. These data reveal that a significant effect was found on plant 
height at 90 days after sowing due to the planting method, where there were significant differences between the FB and RB130, RB100 cm at a $5 \%$ level of significance.

Also, data in Table (4) indicated that a significant effect was found on plant height at 120 days after sowing because of the planting method, there have been significant differences between FB, RB130, RB100, RB80 cm. The plant's height was higher in the FB, RB80 cm, and shorter as the bed width increased $(\mathrm{RB} 100 \mathrm{~cm}, \mathrm{RB} 130 \mathrm{~cm})$, possibly due to the low lateral movement of the water within the wide beds.

Previous findings of sowing methods on plant height did not agree with Soomro et al., (2017), who stated that wheat plant height $(\mathrm{cm})$ was higher under the raised bed irrigation system than the traditional irrigation system. And also with Asif et al., (2020) indicated that there was a significant difference in plant height between the treatments where the highest numbers obtained in bed sowing $(104 \mathrm{~cm})$, followed by ridge sowing $(103 \mathrm{~cm})$ and then flat sowing $(98 \mathrm{~cm})$ in the growing period 2015-16. Also, the previous results weren't in agreement with Ata-ul-karim et al., (2016) that said the results showed the plant height (cm) at maturity was maximum within the case of raised bed planting as compared to the remainder of the sowing methods.

Table (4): Effect of sowing method on plant height

\begin{tabular}{|c|c|c|c|c|c|c|c|c|c|c|}
\hline \multirow{2}{*}{ Treatments } & \multicolumn{3}{|c|}{$\begin{array}{c}\text { plant height at } 90 \text { day } \\
\text { after sowing }\end{array}$} & \multirow{2}{*}{$\begin{array}{c}\text { Mean } \\
\text { cm }\end{array}$} & \multirow{2}{*}{ 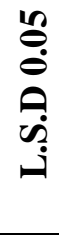 } & \multicolumn{3}{|c|}{$\begin{array}{l}\text { plant height at } 120 \\
\text { day after sowing }\end{array}$} & \multirow{2}{*}{$\begin{array}{c}\text { Mean } \\
\text { cm }\end{array}$} & \multirow{2}{*}{ 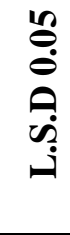 } \\
\hline & $\begin{array}{c}\text { Plot } \\
1\end{array}$ & $\begin{array}{c}\text { Plot } \\
2\end{array}$ & $\begin{array}{c}\text { Plot } \\
3\end{array}$ & & & $\begin{array}{c}\text { Plot } \\
1\end{array}$ & $\begin{array}{c}\text { Plot } \\
2\end{array}$ & $\begin{array}{c}\text { Plot } \\
3\end{array}$ & & \\
\hline Flat-Basin & 85.1 & 82.7 & 79.3 & $82.367^{a}$ & \multirow{4}{*}{$\frac{\vec{b}}{i}$} & 103 & 101.5 & 103.9 & $102.80^{a}$ & \multirow{4}{*}{ 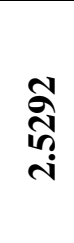 } \\
\hline RB 130 & 84.5 & 80.2 & 75.6 & $80.100^{b}$ & & 98.9 & 93 & 93 & $94.967^{c}$ & \\
\hline RB 100 & 86.1 & 78.4 & 71 & $78.500^{b}$ & & 97.7 & 97.8 & 94.3 & $96.600^{b c}$ & \\
\hline RB 80 & 87.7 & 81.1 & 79.7 & $82.833^{a}$ & & 101.9 & 100.8 & 89.8 & $97.500^{b}$ & \\
\hline
\end{tabular}

Mean with the same letters are not significantly different at $P=0.05$

\section{Number of kernels per spike}

The data in Table (5) shows the number of kernels per spike as a function of the planting method, with no significant $(P=0.05)$ differences between treatments.

Table (5): Effect of sowing method on number of kernels/ spike

\begin{tabular}{|c|c|c|c|c|c|}
\hline \multirow{2}{*}{ Treatments } & \multicolumn{3}{|c|}{ No. of kernels/spike } & \multirow[t]{2}{*}{ Mean } & \multirow{2}{*}{$\begin{array}{c}\text { L.S.D } \\
0.05\end{array}$} \\
\hline & Plot 1 & Plot 2 & Plot 3 & & \\
\hline Flat-Basin & 62.33 & 57.27 & 69.53 & $63.333^{\mathrm{a}}$ & \\
\hline RB 130 & 55.13 & 65.53 & 65.53 & $62.067^{\mathrm{a}}$ & $\hat{\sigma}$ \\
\hline RB 100 & 64.2 & 58.8 & 67 & $63.333^{\mathrm{a}}$ & ळे \\
\hline RB 80 & 73.53 & 58.6 & 59.4 & $63.844^{a}$ & \\
\hline
\end{tabular}

Mean with the same letters are not significantly different at $\mathrm{P}=0.05$ 


\section{Kernels weight per spike (g)}

Table (6) shows the kernel weight per spike (g) as affected by the sowing method, demonstrating that there weren't significant $(p=0.05)$ differences between treatments.

Table (6): Kernels weight per spike (g) as affected by planting method

\begin{tabular}{|c|c|c|c|c|c|}
\hline \multirow{2}{*}{ Treatments } & \multicolumn{3}{|c|}{ Kernels weight spike (g) } & \multirow{2}{*}{$\begin{array}{c}\text { Mean } \\
\text { (g) }\end{array}$} & \multirow{2}{*}{$\begin{array}{c}\text { L.S.D } \\
\mathbf{0 . 0 5}\end{array}$} \\
\hline & Plot 1 & Plot 2 & Plot 3 & & \\
\hline Flat-Basin & 2.865 & 2.558 & 3.418 & $2.9470^{a}$ & \\
\hline RB 130 & 2.751 & 3.387 & 3.282 & $3.1403^{a}$ & $\overline{\mathcal{A}}$ \\
\hline RB 100 & 3.174 & 2.850 & 3.430 & $3.1511^{a}$ & $\tilde{\varrho}$ \\
\hline RB 80 & 3.592 & 2.927 & 2.965 & $3.1615^{\mathrm{a}}$ & \\
\hline
\end{tabular}

Mean with the same letters are not significantly different at $\mathrm{P}=0.05$

\section{Number of spikes per $\mathbf{m}^{2}$}

The number of spikes per $\mathrm{m}^{2}$ of wheat is a key yield parameter that is greatly influenced by planting techniques. At the 5\% level of significance, the results in Table (7) show significant differences between FB and raised beds. While there wasn't statistically significant $(p=0.05)$ differences between RB $130 \mathrm{~cm}, \mathrm{RB} 100 \mathrm{~cm}$, and RB80 cm.

Table (7): Effect of sowing method on number of spike $/ \mathbf{m}^{2}$

\begin{tabular}{|c|c|c|c|c|c|}
\hline \multirow{2}{*}{ Treatments } & \multicolumn{3}{|c|}{ No. of spike /m2 } & \multirow{2}{*}{ Mean } & \multirow{2}{*}{$\begin{array}{c}\text { L.S.D } \\
\mathbf{0 . 0 5}\end{array}$} \\
\hline & Plot 1 & Plot 2 & Plot 3 & & \\
\hline Flat-Basin & 460 & 370 & 520 & $450^{a}$ & \\
\hline RB 130 & 320 & 335 & 343 & $332.67^{\mathrm{b}}$ & ¿ั: \\
\hline RB 100 & 300 & 316 & 280 & $298.67^{b}$ & 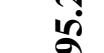 \\
\hline RB 80 & 270 & 300 & 240 & $270^{b}$ & \\
\hline
\end{tabular}

Mean with the same letters are not significantly different at $\mathrm{P}=0.05$

\section{The 1000-grain weight}

Table (8) shows that 1000 kernels weight (g) of the wheat crop was significantly higher for RB $130 \mathrm{~cm}$ than FB, RB80 cm, and RB100 cm, but was not a significant difference between RB100 $\mathrm{cm}$ and RB80 cm. Growing wheat on RB130 $\mathrm{cm}$ yielded the highest average 1000 kernels weight (g) of 50.05 (g), while FB, RB 100, and RB80 cm weighted 45.91, 48.98, and $48.97(\mathrm{~g})$, respectively. The increased weight of 1000 kernels $(\mathrm{g})$ in raised beds-planted wheat may be related to the furrow spacing between raised beds, which allowed more light penetration in the canopy for photosynthesis than wheat planted on flatbeds.

Table (8): Effect of sowing method on 1000 kernels weight (g)

\begin{tabular}{|c|c|c|c|c|c|}
\hline \multirow{2}{*}{ Treatments } & \multicolumn{3}{|c|}{1000 kernels weight $(\mathrm{g})$} & \multirow{2}{*}{$\begin{array}{c}\text { Mean } \\
(\mathrm{g})\end{array}$} & \multirow{2}{*}{$\begin{array}{c}\text { L.S.D } \\
0.05\end{array}$} \\
\hline & Plot 1 & Plot 2 & Plot 3 & & \\
\hline Flat-Basin & 45.834 & 45.500 & 46.408 & $45.91^{c}$ & \\
\hline RB 130 & 49.986 & 49.335 & 50.839 & $50.05^{a}$ & $\mathscr{\theta}$ \\
\hline RB 100 & 48.291 & 48.615 & 49.997 & $48.98^{b}$ & 2 \\
\hline RB 80 & 48.930 & 48.822 & 49.159 & $48.97^{b}$ & \\
\hline
\end{tabular}

Mean with the same letters are not significantly different at $\mathrm{P}=0.05$ 


\section{Wheat yield and harvest index \\ Grain yield (ton/ha)}

One of the most significant considerations deciding the adoption of a certain system of cultivation and not the other is the productivity of the cultivated area. At the 5\% level of significance, the results in Table (9) show significant differences between FB and RB100, RB80 cm, and there weren't significant differences between FB and RB130 cm, nor between $\mathrm{RB} 130 \mathrm{~cm}$ and RB100 $\mathrm{cm}$. Growing wheat on FB resulted in the highest average grain yield (ton/ha) of 8.5907 (ton/ha), while the average grain yield for RB130, RB100, and RB80 cm was 7.9583, 6.3810, and 5.8443 (ton/ha), respectively. Although the RB130 cm method did not achieve the highest productivity, it maintained there weren't significant differences between it and the FB method, which gave the highest productivity, giving the RB130 cm system an adoption advantage over other raised beds. Such results are compatible in that the raised beds with a wide width provide the highest grain yield than the raised beds with a narrow width with the reports of Swelem et al., (2015), who found that sowing wheat on raised beds with widths of 100 or $120 \mathrm{~cm}$ gave the highest significant average of grain yield as well as harvest index compared to the narrowest raised beds width $(75 \mathrm{~cm})$ in the first year. In the second season, the same pattern was observed for grain, biological, and straw yields as well as harvest index.

While these results did not agree in terms of higher productivity of the wheat crop grown on a raised bed than wheat grown in a flat basin with the reports of Asif et al., (2020) that indicated the highest grain yield obtained in bed sowing ( 4.95 tons $^{-1}$ ) that is $16.36 \%$ higher than flat sowing method. Tewabe et al., (2020) said that optimal raised bed width wheat production had a $26 \%$ yield advantage at Koga and a $27 \%$ yield advantage at the Rib irrigation scheme when compared to farmer irrigation practice. Majeed et al., (2015) results showed that wheat planting on beds and nitrogen application at $120 \mathrm{~kg} \mathrm{ha}^{-1}$ achieved $15.06 \%$ higher grain yield than flat planting at the same nitrogen rate. Ahmad et al., (2014) reported that the raised bed planting showed an increase of $11.2 \%$ in grain yield over the flat-sowing method. Akbar et al., (2010) reported that during the first experiment, the wide beds produced higher wheat yields $(15 \%)$ than the flat basin treatment. However, average wheat yields on the medium and narrow beds were only slightly $(5 \%)$ higher than in the basin during the second experiment.

Table (9): Wheat grain yield as affected by planting method

\begin{tabular}{lccccc}
\hline \multirow{2}{*}{ Treatments } & \multicolumn{3}{c}{ Grain yield (ton/ha) } & Mean & L.S.D \\
\cline { 2 - 4 } & Plot $\mathbf{1}$ & Plot 2 & Plot 3 & & $\mathbf{0 . 0 5}$ \\
\hline Flat-Basin & 8.193 & 7.421 & 10.158 & $\mathbf{8 . 5 9 0 7}^{\text {a }}$ & \\
RB 130 & 7.247 & 7.954 & 8.674 & $\mathbf{7 . 9 5 8 3}^{\text {ab }}$ & $\bar{\Xi}$ \\
RB 100 & 5.987 & 7.150 & 6.006 & $\mathbf{6 . 3 8 1 0}^{\text {bc }}$ & $\overline{\mathbf{i}}$ \\
RB 80 & 5.885 & 6.712 & 4.936 & $\mathbf{5 . 8 4 4 3}^{\mathbf{c}}$ & \\
\hline
\end{tabular}

Mean with the same letters are not significantly different at $\mathrm{P}=0.05$

\section{Straw Yield (ton/ha)}

The straw yield was calculated by weighing the biological yield for a one-meter-square sample per plot and subtracting the grain weight for the same one-meter-square. At the 5\% 
level of significance, the results in Table (10) show a significant difference between treatments. The straw yield (ton/ha) for the FB was significantly higher than RB100 and RB80 cm, but there weren't significant differences between the FB and RB130 cm, and also weren't between RB130 cm and RB100, RB80 cm.

Table (10): Straw yield (ton/ha) as affected by planting method.

\begin{tabular}{|c|c|c|c|c|c|}
\hline \multirow{2}{*}{ Treatments } & \multicolumn{3}{|c|}{ Straw yield (ton/ha) } & \multirow{2}{*}{ Mean } & \multirow{2}{*}{$\begin{array}{c}\text { L.S.D } \\
0.05\end{array}$} \\
\hline & Plot 1 & Plot 2 & Plot 3 & & \\
\hline Flat-Basin & 14.357 & 13.929 & 17.592 & $15.293^{a}$ & \multirow{4}{*}{ 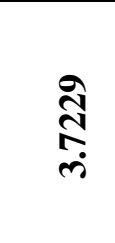 } \\
\hline RB 130 & 9.653 & 13.096 & 12.725 & $11.825^{a b}$ & \\
\hline RB 100 & 9.262 & 8.450 & 13.844 & $10.519^{b}$ & \\
\hline RB 80 & 9.815 & 9.538 & 8.364 & $9.239^{b}$ & \\
\hline
\end{tabular}

Mean with the same letters are not significantly different at $\mathrm{P}=0.05$

\section{Biological Yield (ton/ha)}

The biological yield is the weight of a wheat sample taken after harvesting without the grains separated from the straw. At the 5\% level of significance, the results in Table (11) show significant differences between FB and RB100, RB80 cm. At the 5\% level of significance, there weren't significant differences between FB and RB130 cm, and also weren't between $\mathrm{RB} 130 \mathrm{~cm}$ and $\mathrm{RB} 100, \mathrm{RB} 80 \mathrm{~cm}$.

Wheat straw and biological yields were not significantly affected by sowing on raised beds at widths of 130, 100, and $80 \mathrm{~cm}$. These findings are consistent with those obtained by Swelem et al., (2018) that stated sowing methods in the first season had no significant effect on straw and biological yields of wheat. These reasons may be attributed to adequate soil water conditions for better root development, which increases water and nutrient acquisition on the $\mathrm{RB} 120$ or RB100 cm

Table (11): Biological yield (ton/ha) as affected by planting method

\begin{tabular}{lccccc}
\hline & \multicolumn{3}{c}{ Biological yield (ton/ha) } & \multirow{2}{*}{ Mean } & \multirow{2}{*}{ L.S.D } \\
\cline { 2 - 4 } & Plot 1 & Plot 2 & Plot 3 & & $\mathbf{0 . 0 5}$ \\
\hline Flat-Basin & 22.550 & 21.350 & 27.750 & $\mathbf{2 3 . 8 8 3}^{\text {a }}$ & \\
RB 130 & 16.900 & 21.050 & 21.400 & $\mathbf{1 9 . 7 8 3}^{\text {ab }}$ & \multirow{+}{+}{} \\
RB 100 & 15.250 & 15.600 & 19.850 & $\mathbf{1 6 . 9 0 0}^{\text {b }}$ & \multirow{+}{+}{} \\
RB 80 & 15.700 & 16.250 & 13.300 & $\mathbf{1 5 . 0 8 3}^{\text {b }}$ & \\
\hline
\end{tabular}

Mean with the same letters are not significantly different at $\mathrm{P}=0.05$

\section{Harvest index \%}

Harvest index percent calculated by dividing the amount of grain yield (ton/ha) by the amount of biological yield (ton/ha), and the results were expressed as a percentage. The results in Table (12) show that there weren't significant differences between treatments at the $5 \%$ level of significance.

These findings agree with those of (Saifuzzaman et al., n.d.), who stated that during these trials 2008-09, data from all locations, averaged from beds versus flat-plantings, revealed that no method was superior, at least in these trials. Despite conclusive evidence that there is no 
difference in yield between beds and flat plantings, the researchers involved maintained that beds should be better. In 2009-10, the comparisons were expanded to include more locations. Varieties were the same as in 2008-09, with the addition of BAW 1064 and BAW 1059. There was no consistent or significant advantage for either cultivation method (beds versus flat-plantings) or any variety used for a cultivation method in any region.

Table (12): Harvest index \% as affected by planting method

\begin{tabular}{|c|c|c|c|c|c|}
\hline \multirow{2}{*}{ Treatments } & \multicolumn{3}{|c|}{ Harvest index \% } & \multirow{2}{*}{ Mean } & \multirow{2}{*}{$\begin{array}{r}\text { L.S.D } \\
\mathbf{0 . 0 5}\end{array}$} \\
\hline & Plot 1 & Plot 2 & Plot 3 & & \\
\hline Flat-Basin & 36.333 & 34.759 & 36.605 & $35.899^{a}$ & \multirow{4}{*}{$\underset{\infty}{\stackrel{\infty}{\infty}}$} \\
\hline RB 130 & 42.882 & 37.786 & 40.533 & $40.400^{\mathrm{a}}$ & \\
\hline RB 100 & 39.259 & 45.833 & 30.257 & $38.450^{\mathrm{a}}$ & \\
\hline RB 80 & 37.484 & 41.305 & 37.113 & $38.634^{a}$ & \\
\hline
\end{tabular}

Mean with the same letters are not significantly different at $\mathrm{P}=0.05$

\section{CONCLUSION AND RECOMMENDATION}

\section{Conclusion}

According to the study results, using raised beds cultivation resulted in a 15 21\% reduction in irrigation water compared to a flat basin. Moreover, the rate of irrigation water savings (\%) for wheat sowing on a raised bed at widths of 130 and $100 \mathrm{~cm}$ compared to a raised bed at a width of $80 \mathrm{~cm}$ was 7.95 and $6.75 \%$, respectively, while the rate of irrigation water savings (\%) for a raised bed at widths of $130 \mathrm{~cm}$ compared to a raised bed at a width of $100 \mathrm{~cm}$ was $1.29 \%$. Growing wheat on RB $130 \mathrm{~cm}$ yielded the highest average water productivity of $1.7863 \mathrm{~kg} / \mathrm{m}^{3}$ but growing wheat on FB, RB 100, and RB80 $\mathrm{cm}$ gave $1.508,1.413$, and 1.208 $\mathrm{kg} / \mathrm{m}^{3}$, respectively. Thus, wide beds are preferred over narrow beds because wide beds reduce un-cropped furrow area, increase land-use efficiency, and save water irrigation, all of which improve crop water productivity.

The plant was taller in the $\mathrm{FB}, \mathrm{RB} 80 \mathrm{~cm}$, and shorter as bed width increased $(\mathrm{RB} 100 \mathrm{~cm}$, $\mathrm{RB} 130 \mathrm{~cm}$ ), probably due to the low lateral moving water in the wide beds. The results show significant differences between the FB and raised beds at the 5\% level of significance. The FB irrigation system had the most spikes per $\mathrm{m}^{2}$, followed by the RB130 cm, RB100 cm, and RB80 cm irrigation systems. Raised beds of $130 \mathrm{~cm}$ width yielded the highest significant averages of wheat 1000 kernels weight (g) of 50.05 (g), while FB, RB 100, and RB80 cm gave 45.91, 48.98, and 48.97 (g), respectively. With no significant $(\mathrm{P}=0.05)$ differences in the number of kernels per spike and the kernel weight spike $(\mathrm{g})$ between treatments.

The productivity of the cultivated area is one of the most important factors in deciding whether to use one system of cultivation over another. Wheat grown on FB yielded the highest average grain yield (ton/ha) of 8.5907 (ton/ha), while RB130, RB100, and RB80 cm yielded 7.9583, 6.3810, and 5.8443 (ton/ha), respectively. Besides that, there was no statistically significant difference in straw yield and biological yield (ton/ha) between FB and RB130 cm. Although the RB130 $\mathrm{cm}$ method did not achieve maximum productivity, it maintained that there weren't significant differences between it and the FB method, which did, 
giving the RB130 cm system an advantage over the other raised beds in terms of adoption. Finally, there weren't significant differences between treatments in harvest index per cent at the $5 \%$ level of significance.

\section{Recommendation}

The following recommendation has drawn for the study of the impact of the raised beds technique on wheat productivity, compared to the traditional basin method:

1. Using raised beds with a width of 130 resulted in the least amount of water applied (4456 $\left.\mathrm{m} 3 \mathrm{ha}^{-1}\right)$, the highest average crop water productivity $\left(1.7863 \mathrm{~kg} / \mathrm{m}^{3}\right)$, and the highest significant averages of wheat 1000 kernels weight $(50.05 \mathrm{~g})$, as well as water savings $(21.81 \%)$ over the FB and savings $(7.95 \%),(1.29 \%)$ over raised beds with widths of 80 and $100 \mathrm{~cm}$.

2. The FB method gave the highest significant averages of grain yield, straw yield, and biological yield (ton/ha), but the RB130 cm method maintained that there weren't significant differences between it and the FB method led gives the RB130 cm system an advantage in terms of adoption over other raised bed systems.

Given Egypt's water scarcity, we recommend planting winter wheat on raised beds $130 \mathrm{~cm}$ wide this is due to the essentially significant differences between it and traditional flat basin cultivation and the rest of raised beds cultivation methods.

\section{REFERENCES}

Ahmad R. N. and Mahmood, N. (2005). Impact of Raised Bed Technology on Water Productivity and Lodging of Wheat. Pakistan Journal of Water Resources, Vol.9(2)

Akbar, G., G. Hamilton, \& Raine S. (2010). Permanent raised bed configurations and renovation methods affect crop performance. 19th World Congress of Soil Science, Soil Solutions for a Changing World, August, 171-174.

Akbar, G., et al. (2016). 'Improved soil physical properties, yield and water productivity under controlled traffic, raised-bed farming'. Sarhad J. Agric., 32(4), 325-333.

Akbar, G. (2019). Effect of sowing method on wheat production in Potohar, Pakistan. Pak. J. Agri., Agril. Engg., Vet. Sci., 2019, 35 (2): 98-104

Akbar, G., et al. (2016). Improved Soil Physical Properties, Yield and Water Productivity under Controlled Traffic, Raised-Bed Farming. Sarhad Journal of Agriculture, 32(4), 325-333. https://doi.org/10.17582/journal.sja/2016.32.4.325.333

Ali, M.H., et al. (2007). Effects of deficit irrigation on yield, water productivity and economic returns of wheat. Agricultural Water Management, 92(3), 151-161.

Ata-ul-karim, S. T., \& Akbar, N. (2016). Improvement in Wheat Crop Growth and Grain Yield under Different. December, 71-79.

El-Beltagy, A.T., and Abo-Hadeed A.F. (2008). The main pillars of the National Program for maximizing the water-use efficiency in the old land. $30 \mathrm{p}$. The Research and Development Council. Ministry of Agriculture and Land Reclamation (MOALR), Giza, Egypt (in Arabic). 
Ghani Akbar, G., Hussain, Z., \& Yasin, M. (2007). Problems and potentials of permanent raised bed cropping systems in Pakistan. Pakistan Journal of Water Resources, 11(1), 11.

ICARDA. (2020). Gender and Agriculture in Egypt. Women in Agriculture in the Middle East, July, 125-150. https://doi.org/10.4324/9781315233765-12

Jat, M. L., et al. (2011). Layering Precision Land Leveling and Furrow Irrigated Raised Bed Planting: Productivity and Input Use Efficiency of Irrigated Bread Wheat in IndoGangetic Plains. American Journal of Plant Sciences, 02(04), 578-588. https://doi.org/10.4236/ajps.2011.24069

Khalifa, E. S., Okasha, A., \& Shawat, S. (2019). Development of Surface Irrigation Using Surge Irrigation Technique. Journal of Fresenius Environmental Bulletin, 28(4 A), 3121-3130.

Klute, A.C (1987). Methods of Soil Analysis, Part 1 (Physical and Mineralogical Methods). Agronomy Monograph Nr. 9, Second Edition. Verlag Amer. Soc. Agron. und Soil Sci. Soc. Amer., Madison (Wisconsin), USA. https://doi.org/10.1002/jpln.19871500519

Kukal, S. S., et al. (2010). Factors affecting irrigation water savings in raised beds in rice and wheat. Field Crops Research, 118(1), 43-50. https://doi.org/10.1016/j.fcr.2010.04.003

Majeed, A., et al. (2015). Bed planting of wheat ( Triticum aestivum L.) improves nitrogen use efficiency and grain yield compared to flat planting. The Crop Journal, ScienceDirect CJ, 3(2), 118-124. https://doi.org/10.1016/j.cj.2015.01.003

Roth C.H., et al. (2005). Evaluation and performance of permanent raised bed cropping systems in Asia, Australia and Mexico. Proceedings of a workshop held in Griffith, Australia, 1-3 March 2005. ACIAR Proceedings No. 121. (ISBN 186320506 3)

Saifuzzaman M., et al. (2011). Optimising Wheat Production thtough 3.5 Beds or flat-planting for southern wheat crops. ACIAR Technical Report No. 78 Australian Center for International Agriculture Research (ACIAR), Australia pp. 163-169

Swelem, A.A. ; Manal A. Hassan and E.A.M. Osman (2015). Effect of Raised Width and Nitrogen Fertilizer Level on Productivity and Nutritional Status of Bread Wheat. Egypt . J. of Appl. Sci., 30 (3) 2015, 223-234.

Soomro, S. (2017). Evaluation of Raised-Bed and Conventional Irrigation Systems for Yield and Water Productivity of Wheat Crop. Journal of Basic \& Applied Sciences, 13(May), 143-149. https://doi.org/10.6000/1927-5129.2017.13.24

Ismail S. (1993). Optimal irrigation and wheat yield response to applied water. Journal of King Saud University 5:41-56.

Swelam, A. (2017). Raised-bed planting in Egypt: an affordable technology to rationalize water use and enhance water productivity. November. https://apps.icarda.org/wsInternet/wsInternet.asmx/DownloadFileToLocal?filePath=Science_Im pacts/science_impact_raised_bed.pdf\&fileName=science_impact_raised_bed.pdf 
Tewabe, D., et al. (2020). Determination of bed width on raised bed irrigation technique of wheat at Koga and Rib Irrigation Projects, North West, Ethiopia. Cogent Food \& Agriculture, 6(1). https://doi.org/10.1080/23311932.2020.1712767

Zaman, R., et al. (2018). Effect of Deficit Irrigation on Raised Bed Wheat Cultivation. Cercetari Agronomice in Moldova, 50(4), 17-28. https://doi.org/10.1515/cerce-20170032 
التأثثر المقارن للري بالمصاطب وبالأحواض المستوية التقليدية علي إنتاجية القمح والمياه في ظل الظروف المصرية

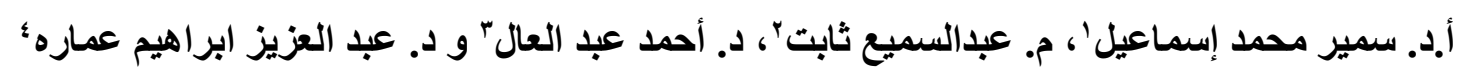

' ' استاذ هندسة الري و الصرف ـ قسم الهندسة الزر اعية و النظم الحيوية ـ كلية الزراعة ـ جامعة الأسكندرية ـ مصر.

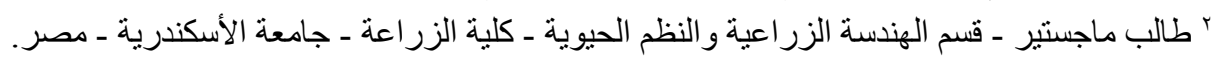

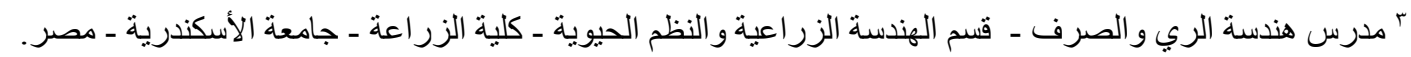

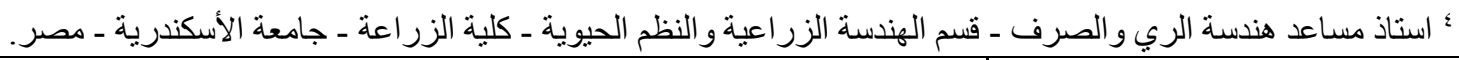

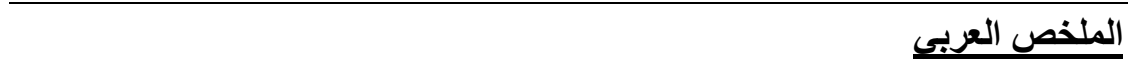

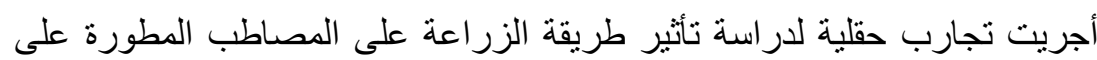

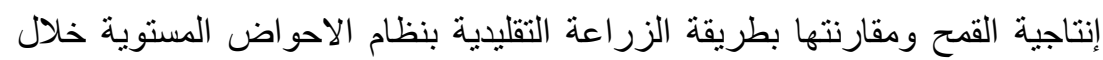

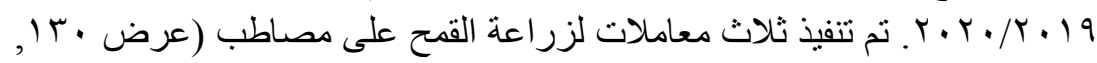

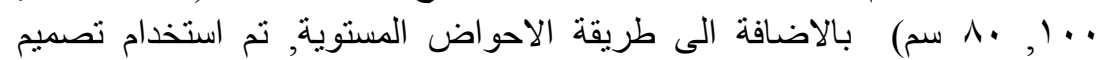

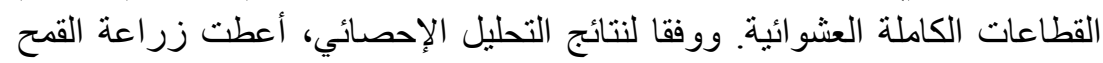

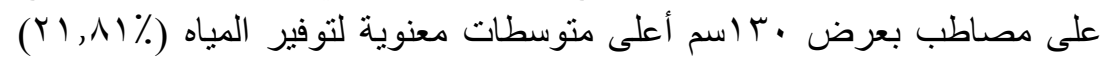

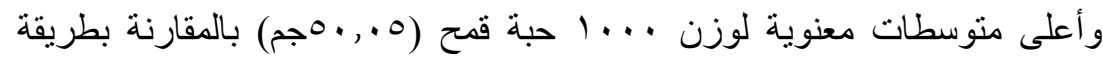

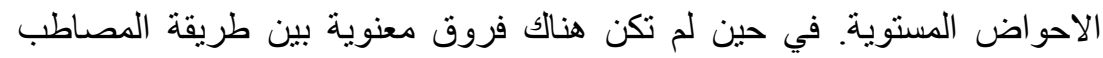

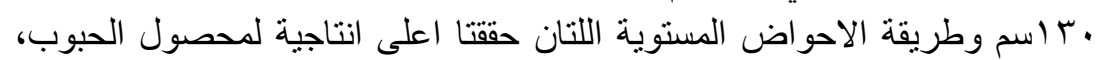

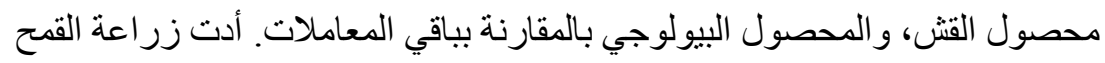

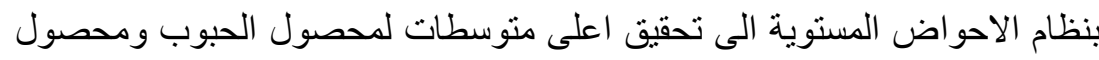

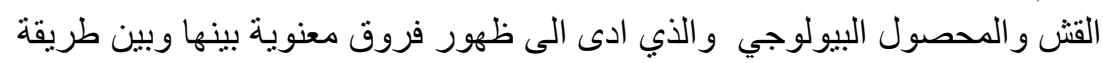

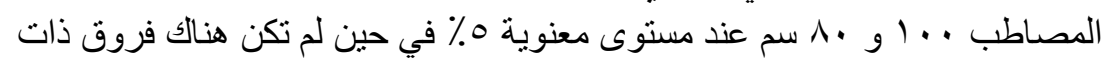

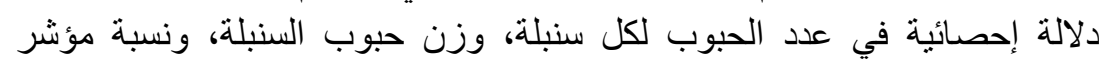

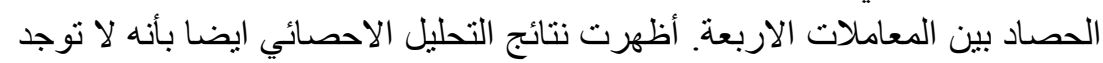

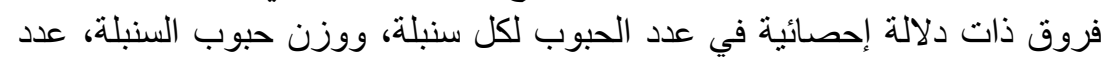

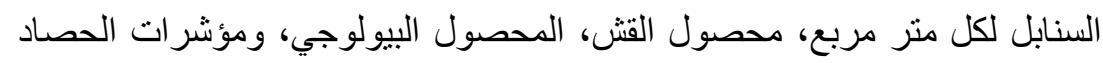

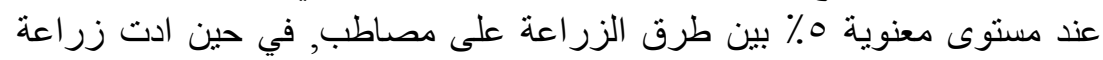

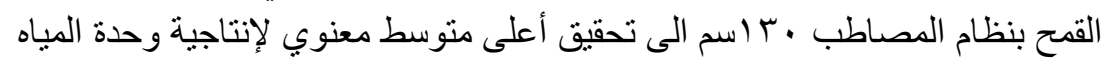

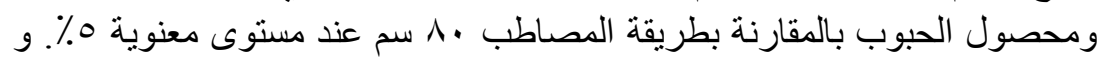

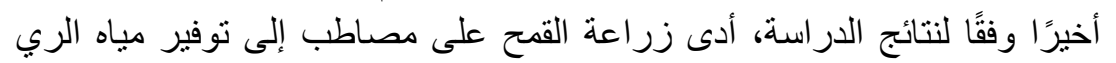

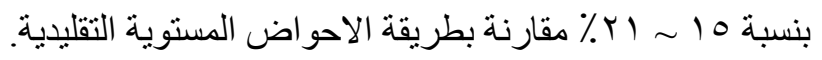

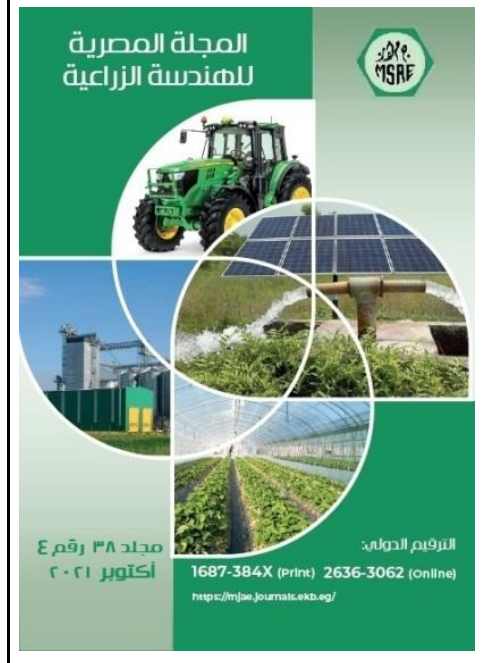

(المجلة المصرية للهندسة الزراعية

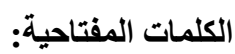

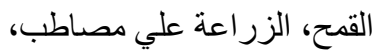
توفير المياه 